\title{
Effective reassessments of freshwater fish species: a case study in a Mediterranean peninsula
}

\author{
Imanol Miqueleiz $($ D $\cdot$ Rafael Miranda (D) Arturo H. Ariño $(\mathbb{D} \cdot$ Tommaso Cancellario
}

Received: 27 November 2020/Revised: 9 June 2021 / Accepted: 14 June 2021 / Published online: 6 July 2021

(C) The Author(s) 2022

\begin{abstract}
IUCN Red List assessments for fish species can quickly become out of date. In recent years molecular techniques have added new ways of obtaining information about species distribution or populations. In this work, we propose the Iberian Peninsula as an example of reassessment needs in its endangered freshwater fish fauna. We compiled the list of freshwater fish species occurring in continental Spain and Portugal and examined their conservation status in global and national Red Lists. We retrieved records for these species in the Iberian Peninsula and calculated several biological indexes (richness and vulnerability indexes). Our results showed a patchy data coverage of fish records in the Iberian Peninsula. Threat levels reported within national Red Lists are higher than their global counterparts, reinforcing the necessity of improving and maintaining up to date national Red Lists. Iberian watersheds have moderate
\end{abstract}

Guest editors: Javier Sánchez-Hernández \& Rufino

Vieira-Lanero / Insights and Advances in Iberian Ichthyology

Supplementary Information The online version contains supplementary material available at https://doi.org/10.1007/ s10750-021-04644-4.

I. Miqueleiz $(\bowtie) \cdot$ R. Miranda · A. H. Ariño .

T. Cancellario

Biodiversity Data Analytics and Environmental Quality (BEQ) Group, Institute of Biodiversity and Environment (BIOMA), Universidad de Navarra, Irunlarrea 1,

31008 Pamplona, Navarra, Spain

e-mail: imiqueleiz@alumni.unav.es levels of threat and high levels of out of date assessments. The nearly fully completed genetic databases for Iberian fish species, along with the limited distribution of many endangered species and the necessity of update their assessments constitute an excellent opportunity to use data obtained from eDNA to improve species monitoring practices and their conservation status.

Keywords Freshwater fish - Iberian Peninsula . National Red Lists · Out of date assessments

\section{Introduction}

The Earth is home of more than 1.2 million described species and many others remain undiscovered (Mora et al., 2011). Currently, species extinction rates have been estimated to be 1000 times faster than those registered in the fossil record (De Vos et al., 2015) and the sixth mass extinction (Ceballos et al., 2017) is one of the most relevant issues occurring in the XXI century. Ecosystems are losing their biodiversity at too high rates mainly due to anthropogenic causes such as climate change, species invasions and habitat alteration (Dudgeon et al., 2006; Dirzo et al., 2014; Reid et al., 2019). Among all ecosystems, inland waters are one of the most affected (Strayer \& Dudgeon, 2010; Collen et al., 2014). Wetlands are disappearing three 
times faster than forests (Ramsar Convention on Wetlands, 2018) and freshwater vertebrate populations decrease faster than their terrestrial or oceanic relatives (WWF, 2020). Although freshwaters cover a very restricted area on the Earth (Lehner \& Döll, 2004), they host almost $10 \%$ of all described species (Strayer \& Dudgeon, 2010) including 18,000 fishes (Fricke et al., 2020). Fishes are among the most charismatic and good studied organisms that inhabit freshwater and nowadays may be considered the most threatened vertebrate group (Hughes, 2021). Moreover, their endemism level is incredibly high (Pelayo-Villamil et al., 2015; Tedesco et al., 2017), and their loss could be an irreparable consequence of global biodiversity.

To inform about species extinction risk, the International Union for the Conservation of Nature (IUCN) has developed since 1964 the IUCN Red List. From its begin, IUCN Red List has become an increasingly powerful tool for conservation planning, management, monitoring, and decision making (Rodrigues et al., 2006). Nowadays, almost 10,000 freshwater fish species have been assessed, and approximately $23 \%$ are currently threatened with extinction (IUCN, 2020). However, their assessment rate remain below compared to any other vertebrate group (Tapley et al., 2018; Miqueleiz et al., 2020).

To fix this gap and optimize the efficiency of IUCN Red List, many efforts are focusing on identifying priority assessment areas (Hermoso et al., 2017) and evaluating threat risk for total freshwater fish (Global Freshwater Fish Assessment, IUCN, 2020). Nevertheless, the number of freshwater fish without updated assessments (evaluations with less than ten years) (Rondinini et al., 2014) is high ( $\sim 32 \%$ of total evaluated freshwater fish) (IUCN, 2020), and this lag can seriously affect the reliable information about their conservation status (Rondinini et al., 2014). Furthermore, many revaluated fishes have undergone a not genuine change (mainly because new information has become available since the last assessment), and fish with genuine change have risen their threat status, according to IUCN Red List statistics. This calls for a reconsideration of the importance of the reassessment process and the necessity of maintain up to date evaluations.

Parameters about population size and structure, and distribution range are required to obtain a reliable conservation status from IUCN Red List. Still, the acquisition of these data with traditional survey methods (e.g., electric fishing) is time-consuming, expensive (Rondinini et al., 2014), and most of the times inefficient to detect rare or elusive species (Beng \& Corlett, 2020). In a conservation underfunding context (Waldron et al., 2013), periodically reassessment of freshwater fish populations might only be possible if the evaluation becomes more efficient and fast.

In the last decade, the use of non-invasive molecular techniques (e.g., eDNA) is raising increased attention (Antognazza et al., 2019) and their application in monitoring and conservation projects has rapidly grown. These techniques may provide the opportunity to map species geographic distribution over long periods and across large spatial scales (Sales et al., 2021). They could also offer greater probabilities of detection of cryptic species if compared with the use of traditional sampling procedures. Despite its limitations (Beng \& Corlett, 2020), there is a wide consensus that a molecular approaches can become a powerful tools to ease and improve species conservation assessments. However, nowadays they cannot be used as the main techniques, as its utility for detecting other parameters as species abundance or biomass is yet to be fully understood. Currently, we are in a transition period where traditional electrofishing and molecular techniques coexist, and its combination is the best solution until the complete development of eDNA and other tools to assess a wider range of parameters.

Among the several biodiversity hotspots where species knowledge and reassessment needs to be improved (Myers et al., 2000), in this work, we focused on the freshwater habitat in the Iberian Peninsula. The hydrology system of the Iberian Peninsula, composed by several independent river basins, is isolated from the rest of Europe since the rise of the Pyrenees (80-20 million years ago) (Arranz et al., 2011). Due to this high number of independent river basins, freshwater fish populations in Iberian Peninsula are strongly isolated (Clavero et al., 2004) and this explains the low number of families, the high degree of species diversification, and the greatest European percentage of endemism (80\%) (Doadrio et al., 2011). Despite its uniqueness, Iberian freshwater fish are jeopardized by various threats, such as water extraction, reservoirs (also including channelization) and invasive species (Maceda-Veiga, 2013), shared with other Mediterranean regions (Cuttelod et al., 2008; Hermoso \& Clavero, 2011). The IUCN Red List has evaluated the conservation status of many Iberian 
freshwater fish species, resulting in a high number of species being threatened by extinction, similarly to other regions around the Mediterranean (Darwall \& Smith, 2006). Nevertheless, Iberian freshwater fish species require reassessment efforts that must be done not only at global scale but also locally, to allow specific conservation actions at national level. Many countries have already developed national red lists, red data books, or threatened species lists exist that provide fundamental information to inform about the state of biodiversity and report on trends in biodiversity loss (Zamin et al., 2010), but they need to be up to date.

The objective of this study is primarily, to identify the basins of Iberian Peninsula with high fish vulnerability and with the great number of out date evaluations of IUCN Red List. Moreover, we also propose a critic discussion about the potential perspective of using molecular techniques as eDNA in conservation approaches.

\section{Materials and methods}

Fish checklist

The Iberian freshwater fish checklist was created by merging data from two national datasets: (i) for Spanish freshwater fish, we retrieved the data from Spanish Freshwater Fish Database, a resource developed by the Spanish Society of Ichthyology (SIBIC) comprising data and occurrences from freshwater fish species present in peninsular Spain (SIBIC, 2017). (ii) For Portugal, we consulted the list from a Portuguese publication on the topic (Almeida et al., 2019). Each species was labeled based on their origin, as native if autochthonous or introduced if allochthonous. Final taxonomic checklist contains all freshwater fish reported in Iberian Peninsula, comprising freshwater resident species, anadromous and catadromous species and also species present in coastal lagoons.

Subsequentially, IUCN Red List conservation status and assessment date was added using global IUCN Red List (IUCN, 2020) and national Red Lists evaluations obtained for Spain (Doadrio et al., 2011) and Portugal (Alves \& Bochechas, 2005). The final freshwater fish checklist can be found in Supplementary Table S1.
Finally, for each species geographic information was added downloading the georeferenced occurrences from Global Biodiversity Information Facility (GBIF, 2020), using rgbif package (Chamberlain et al., 2014), and the Spanish Freshwater Fish Database (SIBIC, 2017). Both datasets were used to achieve the best distribution cover for each species in the Iberian Peninsula. We merged both datasets and removed records with duplicate coordinates. Furthermore, only those records after 1990 were selected, to avoid species historical occurrences from biasing the analysis and focus only on actual species range.

\section{Data analyses}

Only native species were used for further analysis. To assess the completeness of freshwater fish distributional information and to detect areas with reliable inventories we used the KnowBR package (Guisande \& Lobo, 2019). Parameters set in the $\operatorname{KnowB}()$ function were as follow: cutoffSlope $=0.1 ; x l=6.1$; $x r=6.3$; cell $=10$.

Detection of areas with a high number of native threatened species (evaluated as Vulnerable, Endangered and Critically Endangered) was a prerogative of this work. To do that, a density map was estimated using the package statspat (Baddeley \& Tuner, 2005), using the function density.ppp() setting the sigma $=$ bw.ppl () .

Finally, we calculated the richness, the Vulnerability Index, and the number of species with out of date assessments for all Iberian basins. We downloaded the Iberian basins shapefile from MARS project (http:// www.mars-project.eu/index.php/databases.html). Basin species richness was calculated using biomonitoR package (Laini et al., 2018). Vulnerability Index was calculated from Abellán et al., (2005) using the conservation status of the species recorded in each basin. Each species was assigned a score based on its IUCN Red List category (Least Concern: 1; Near Threatened: 2; Vulnerable: 3; Endangered: 4; Critically Endangered: 5). A basin score was calculated as complementary of the sum of the vulnerability scores for each species present in that basin divided by the species richness of that basin.

Vulnerability Index $=1-\sum_{i=1}^{S} \frac{\left(\frac{1}{V_{i}}\right)}{S}$ 
where $V_{i}$ is the vulnerability score of species $i$ and $S$ is the species richness of the basin.

All the analyses were performed with $\mathrm{R}$ software ( $\mathrm{R}$ Development Core Team, 2019).

\section{Results}

Georeferenced data were available for all freshwater Iberian fish. Nevertheless, the geographical distribution of the sample points did not follow a regular pattern. Middle and southern areas of Spain and the south of Portugal presented low or null completeness. In comparison, northern Spain is characterized by high completeness and the highest number of records as spots (Fig. 1).

From 97 freshwater fish species listed in the Iberian Peninsula, 71 of them (72\%) were native. Specifically, we found 19 unique native species from Spain and 11 from Portugal, whereas 41 were shared from both. The percentage of assessed species in the global IUCN Red List was higher in Spain (58 assessed species, 98\%) than in Portugal $(48,92 \%)$, with a total of $66(94 \%)$ native species assessed in the Iberian Peninsula. Threatened species (classified as Vulnerable, Endangered or Critically Endangered) in the Iberian Peninsula were 33 (50\% of native species assessed), similar to those classified as Least Concern $(32,48 \%)$, and are mainly concentrated in southwestern, northwestern and eastern Peninsula (Fig. 2). When examining national Red Lists, we found that Spanish freshwater fish were, on average, evaluated at higher threat categories compared to the global one (Fig. 2). In the case of Portugal, the absence of national evaluations for several species did not allow us to identify a similar trend, as many species are evaluated in the global list but not in the national one.

Freshwater fish richness in the Iberian Peninsula was mainly gathered in the Atlantic watersheds of the Southwestern, overall, in the Tagus and Guadiana Rivers, apart from a high diversity spot in the lower Ebro River (Fig. 3). However, the Vulnerability Index in the Iberian Peninsula showed that higher vulnerability values were observed in the Mediterranean basins (except Ebro River), Guadalquivir, Guadiana, and Tagus basins (Fig. 3).

Out of date assessments were detected in 47 species (77\%) of in the Iberian Peninsula, with similar values for Spain (76\%) and Portugal (75\%). By basins, the highest number of out of date assessments were found in the Guadiana River basin and the lower reaches of the Ebro River Basin (Fig. 3).

When we combined species richness, vulnerability and out of date assessments, we found that high values of out of date assessments and vulnerability widespread within the Iberian Peninsula did not allow us to observe a pattern to prioritize reassessment efforts.
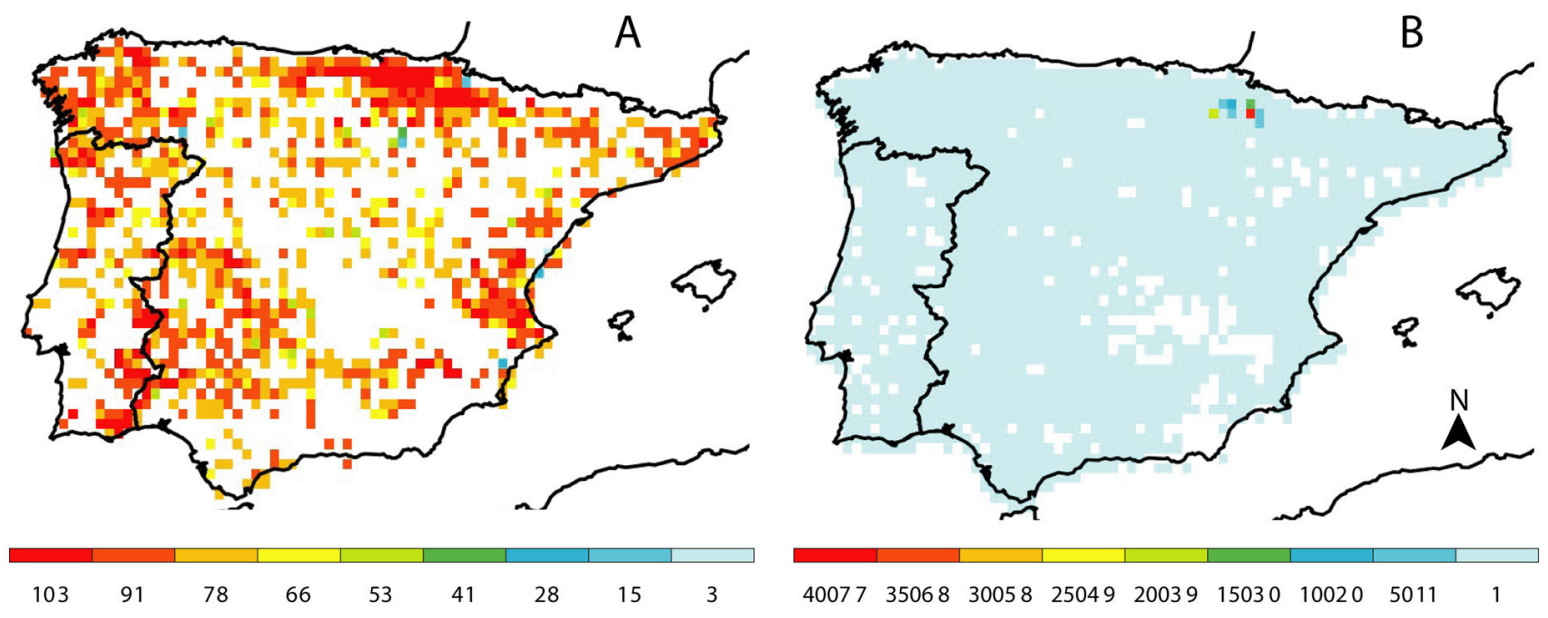

Fig. 1 Completeness (A) and number of record (B) of Iberian freshwater fish resulting from KnowBR 


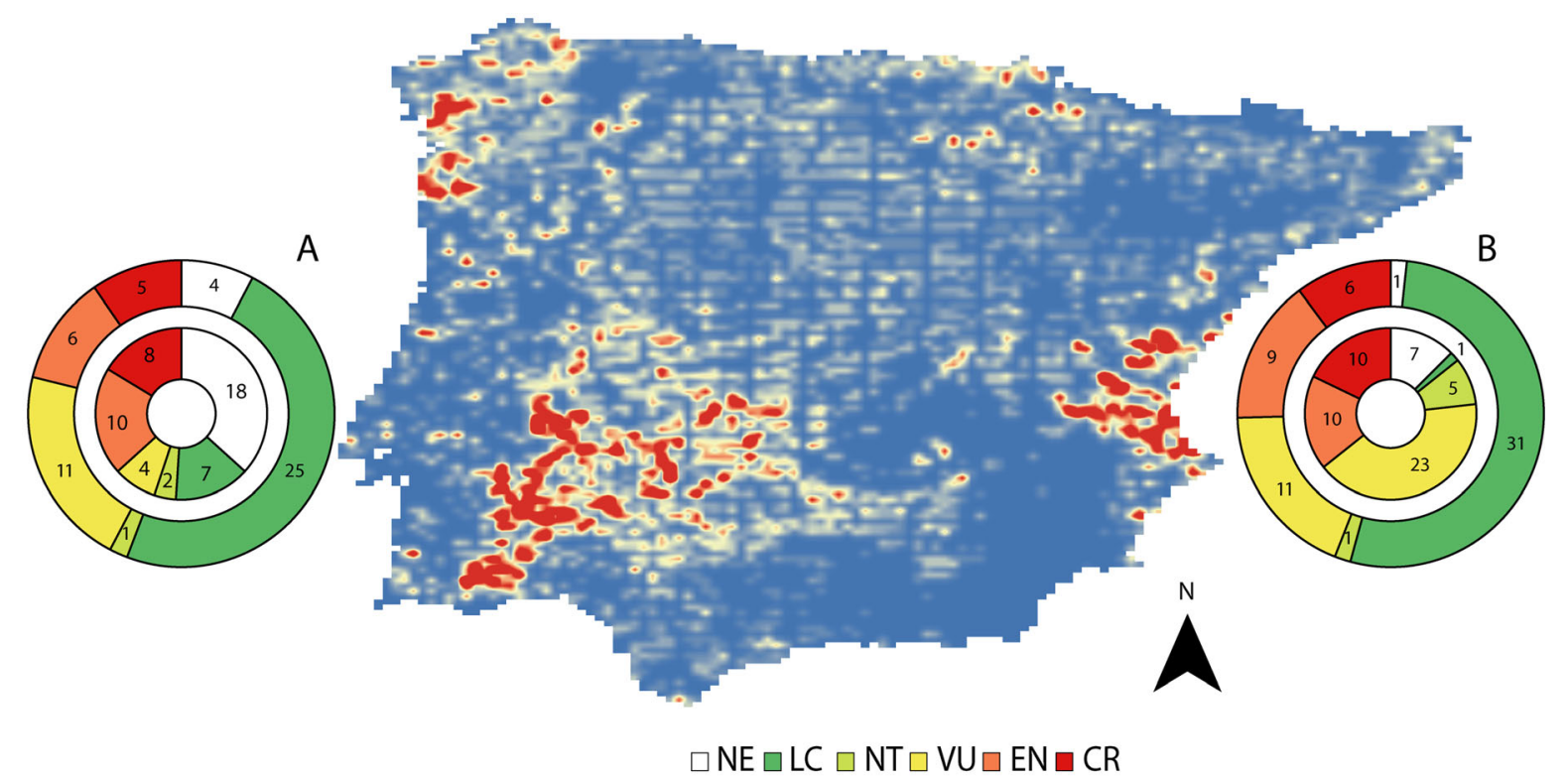

Fig. 2 The rings (A: Portugal; B: Spain) represent the number of species belonging to IUCN Red List categories. The outer ring is relative to the Global IUCN Red List, while the inner on is relative to the National IUCN Red List. NE not evaluated; $L C$

\section{Discussion}

Our study intends to serve as a useful tool to guide future freshwater fish reassessments in the Iberian Peninsula. In fact, we think that similar approaches could be taken in other Mediterranean countries with similar characteristics of species endemism and out of date assessments.

Firstly, our results were strongly biased by current species knowledge and data coverage. Despite having combined data from two sources (Spanish Freshwater Fish Database and GBIF) to achieve the most complete coverage of freshwater fish in the Iberian Peninsula, we found several assessment uncertainties in the checklist that we developed. For instance, the Atlantic sturgeon (Acipenser sturio Linnaeus, 1758) was considered as part of Spanish freshwater ichthyofauna, though it is not present as stable populations in Iberian Peninsula (Gessner et al., 2010). Or also the wide distribution of the European eel (Anguilla anguilla Linnaeus, 1758) within the Iberian Peninsula, as a result of adults released in rivers rather than stable populations (Clavero \& Hermoso, 2015). The records of these two Critically Endangered species may affect the results obtained in these and other analyses which combine species presence and least concern; $N T$ near threatened; $V U$ vulnerable; $E N$ endangered; and $C R$ critically endangered. Map: density of threatened (VU, EN and CR) freshwater fish in the Iberian Peninsula, from low (blue) to high (red)

conservation status. We thus suggest that next publications of National Red Lists in the Iberian Peninsula, and likely in other territories (Zamin et al., 2010), should consider current species distribution and not be driven by historical or speculative considerations.

Regarding species occurrence data, higher species richness was found in the south western basins of the Iberian Peninsula, overall in the Guadiana Basin, which harbors a high number of endemic species (Filipe et al., 2004). Similarly, higher levels of threat in central and southern Iberian Peninsula are related to a higher level of endemism found in these rivers (Elvira, 1995), especially in basins with low richness. We found no significant way of prioritizing freshwater fish reassessments as many basins in the Iberian Peninsula combine moderate or high levels of threat with a high proportion of freshwater fish in need of reassessment. This calls, and provides an opportunity, for developing future reassessment projects to promote endangered species conservation which should be developed all over the region.

We consider that more efforts are needed to achieve and maintain long-term data series of species presence and population trends in Iberian freshwaters, as many regions lacked sufficient data. Long-term monitoring has been used in recent studies in the Iberian 

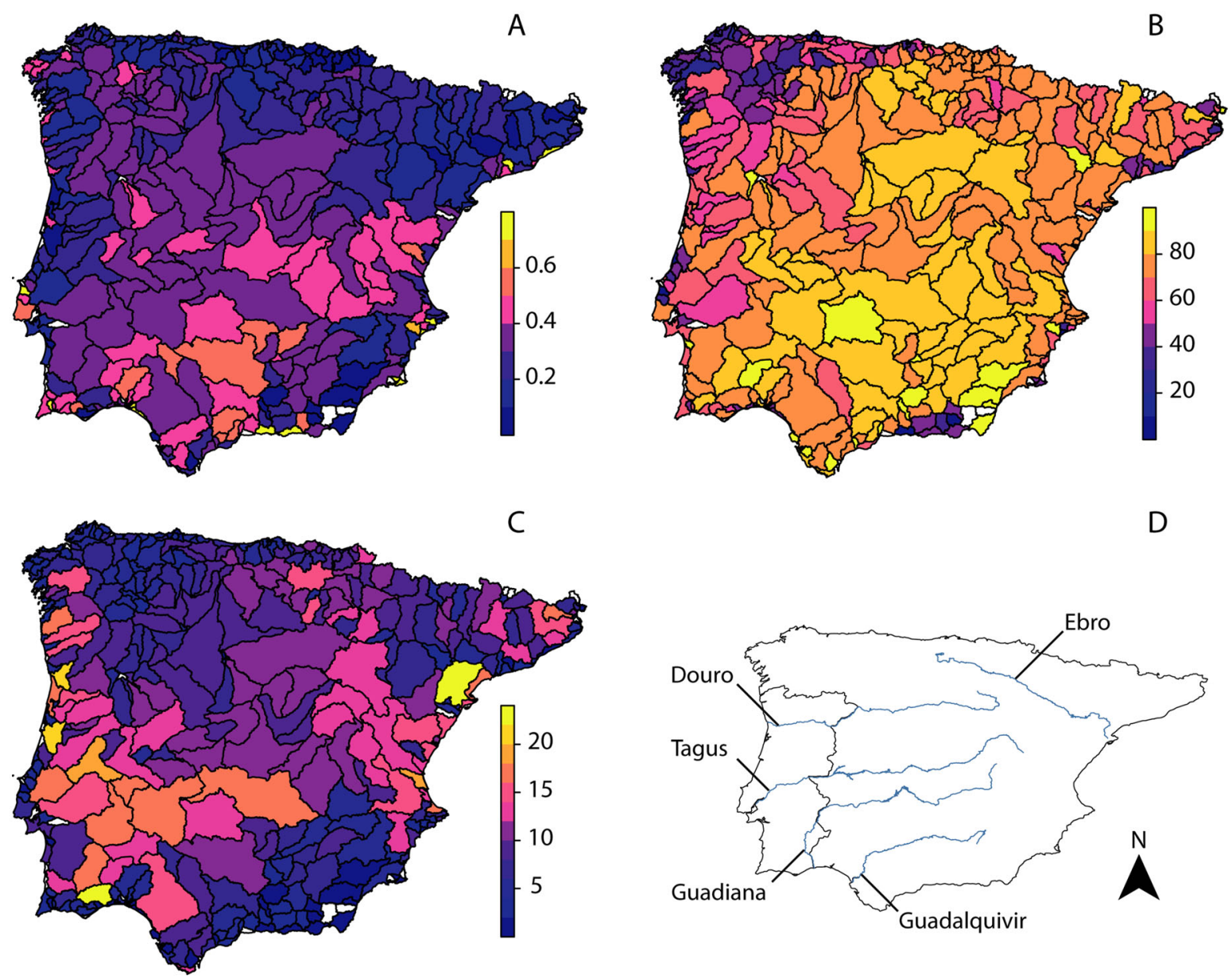

$\mathrm{D}$

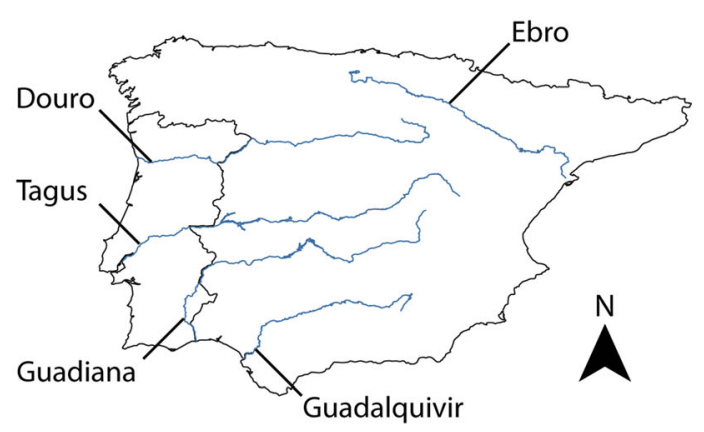

Fig. 3 Freshwater fish indices in the basins of the Iberian Peninsula. Vulnerability Index (from low to high vulnerability) (A), percentage of assessed species with out of date assessments $(\mathbf{B})$, species richness $(\mathbf{C})$ and main rivers in the Iberian Peninsula $(\mathbf{D})$

Peninsula, addressing freshwater fish conservation status from spatial and temporal variations in density and biomass (Sánchez-Hernández et al., 2015). We need accurate data to generate information and build knowledge to inform decision-makers or develop indicators to track progress towards biodiversity goals (Juffe-Bignoli et al., 2016). Furthermore, these data should be available in public repositories as sharing primary biodiversity data is fundamental to the advancement of science as it is currently practiced (Huang et al., 2012) and manage biodiversity change (Kissling et al., 2018). The data-sharing of Iberian fish diversity may help us better represent their native communities and avoid the expansion of invasive species. Implications of invasive species in freshwater Mediterranean environments have been widely studied (Vila-Gispert et al., 2005) and the Iberian Peninsula (Clavero \& Garcia-Berthou, 2006; MuñozMas \& García-Berthou, 2020). Currently, efforts are being developed to increase the knowledge and awareness of the general public about these problems, such as the LIFE Project INVASAQUA (Casals \& Sánchez-González, 2020).

Assessment rates of Iberian freshwater fish remained high, with a low number of native fish species out of the IUCN Red List. Nevertheless, many of these assessments dated from before 2010 and according to IUCN Red List guidelines, they were out of date and should be redone shortly. Furthermore, National Red List of Spain (Doadrio et al., 2011) and Portugal (Alves \& Bochechas, 2005) were out of date too and, in the case in Portugal, did not assess many of 


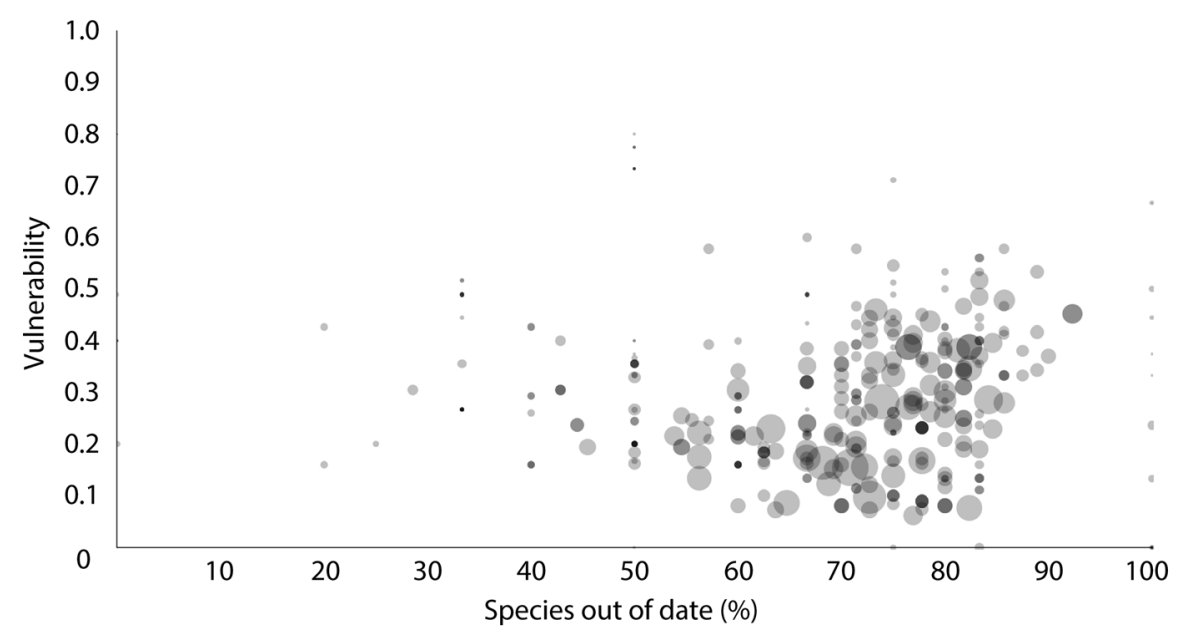

Fig. 4 Values of richness (circle size), inverse vulnerability, and percentage of out of date species in Iberian freshwater basins

the native species. National Red Lists showed higher levels of threat for native species than the global ones. These results contradict previous works (Brito et al., 2010), and suggest that many species with an adequate conservation status could actually have populations closer to extinction in the Iberian Peninsula. However, all these assumptions must be contrasted with current and reliable evaluations, based on recent distribution and population data. Furthermore, in the case of Spain there is an effort duplicity as the current National Red List is not official, whereas conservation priorities are driven by the species included in the Spanish National Catalogue of Endangered Species. We consider that a reliable and authoritative National IUCN Red List, elaborated following the IUCN Red List criteria and procedures, should be the guideline for conservation, and that duplicated efforts should be avoided for the sake of species conservation and to better optimize conservation financial resources. Moreover, submitting Red List assessments of national endemics are equivalent to global scale assessments and would contribute to the update of global Red List (Rodríguez, 2008), as some countries are already doing (Instituto Chico Mendes de Conservação da Biodiversidade, 2018; Contreras-MacBeath et al., 2020).

The isolation of the Iberian Peninsula implies different conservation perspectives for both endemic and European species which lie at the edge of their range and whose conservation status is different from that in the rest of the continent. We consider that both countries have enough species to contemplate feasible projects to reevaluate the conservation status of their freshwater fish faunas. In this sense, we encourage the development of projects which use new techniques as eDNA to evaluate their efficiency against traditional electro-fishing methods (Itakura et al., 2019) and provide us with new sampling protocols for better species monitoring. In fact, several European initiatives working on molecular biomonitoring of freshwater ecosystems as the DNAqua net (www.dnaqua. net) have been carried out in developing molecular biomonitoring of freshwater ecosystems have been carried out in developing molecular biomonitoring of freshwater ecosystems. Fish constitute an optimal example to develop such techniques as their presence in genetic libraries is higher than other freshwater taxa (Weigand et al., 2019). The use of eDNA for conservation purposes remains mainly unexplored in the Iberian Peninsula, despite Iberian freshwater fish fauna is widely covered in genetic libraries. Molecular marker COI has been sequenced for $98 \%$ Iberian fish species (Múrria et al., 2020) and offers valuable opportunities as a tool to obtain data concerning species presence that can be effectively combined with traditional sampling methods (Takahara et al., 2020). Previous works recommend $12 \mathrm{~S}$ as a better marker for freshwater fish monitoring as it offers high specificity (Collins et al., 2019), but its coverage in genetic libraries is smaller (Weigand et al., 2019), at least at European level. Thus, we recommend further efforts to incorporate freshwater fish $12 \mathrm{~S}$ sequences in genetic libraries, provided its efficiency for fish monitoring. 
Environmental DNA is especially useful when dealing with endangered species, as it does not require repeated samplings that would involve huge amounts of time and effort (Stewart, 2019) and potential damage to the populations. One of the main limitations of eDNA is its application to obtain species abundance to establish population trends (Beng \& Corlett, 2020). This issue has been addressed in previous studies with promising results (Itakura et al., 2019) and the combination of traditional sampling methods with eDNA studies can shed light on this complicated issue. In addition, the existence of several hybrids among Iberian species (Doadrio et al., 2011) may provide an opportunity for eDNA to be used when selecting pure populations for reintroductions or ex-situ conservation programs (Marcos et al., 2018). Molecular marker COI did not correctly separate hybrids (Gante et al., 2015) as only maternal lineages are assessed. Thus, improving nuclear markers (as 12S) coverage in genetic libraries also becomes important to deal with hybrids. Finally, considering that many of the species subject of this study are Iberian endemisms, this situation offers the opportunity to develop cooperative projects among different administrations, as freshwater conservation should not understand of political borders.

Significant human resources, structures, and procedures are required to make continuous reassessments possible (Juffe-Bignoli et al., 2016). Without a stable financial and institutional support, there is little chance of establishing long-term monitoring policies that can help to protect both freshwater fish species and the aquatic systems where they live. Previous works have already drafted a proposal for a form of stable survey methodology in Spain (Doadrio et al., 2011), and can serve as a starting point to incorporate eDNA and turn it into a stable, reliable and overall applicable methodology to perform global and national Red Lists.

\section{Conclusions}

Better data coverage is needed in the Iberian Peninsula to adequately estimate freshwater fish species presence in aquatic environments. Furthermore, freshwater fish species with outdated assessments are widespread across the Iberian Peninsula, as well as threatened ones. Thus, they require future reassessment efforts, priority through the development of long-term and stable national Red Lists. The almost complete presence of these species in genetic databases opens the gate of the use of eDNA to develop new species monitoring methodologies and improve species assessment processes.

Acknowledgements We would like to acknowledge the Association of Friends of the University of Navarra for the financial support for I. Miqueleiz. and T. Cancellario. We would also like to acknowledge F. Ribeiro for his help with the Portuguese freshwater fish list.

Funding Open Access funding provided thanks to the CRUECSIC agreement with Springer Nature. I. Miqueleiz. and T. Cancellario were supported by the Association of Friends of the University of Navarra.

Open Access This article is licensed under a Creative Commons Attribution 4.0 International License, which permits use, sharing, adaptation, distribution and reproduction in any medium or format, as long as you give appropriate credit to the original author(s) and the source, provide a link to the Creative Commons licence, and indicate if changes were made. The images or other third party material in this article are included in the article's Creative Commons licence, unless indicated otherwise in a credit line to the material. If material is not included in the article's Creative Commons licence and your intended use is not permitted by statutory regulation or exceeds the permitted use, you will need to obtain permission directly from the copyright holder. To view a copy of this licence, visit http://creativecommons.org/licenses/by/4.0/.

Data availability All data were obtained from public and open-access repositories.

Code availability All code used in the study is explained in the manuscript.

\section{References}

Abellán, P., D. Sánchez-Fernández, J. Velasco, \& A. Millán, 2005. Conservation of freshwater biodiversity: A comparison of different area selection methods. Biodiversity and Conservation 14: 3457-3474.

Almeida, P. R., M. T. Ferreira, F. Ribeiro, B. R. Quintella, C. S. Mateus, \& C. M. Alexandre, 2019. Peixes In Feio, M. J., \& V. Ferreira (eds), Rios de Portugal: Comunidades, processos e alterações. Imprensa da Universidade de Coimbra, Coimbra.

Alves, M. J., \& J. Bochechas, 2005. Peixes In Cabral, M. J., J. Almeida, P. R. Almeida, T. Dellinge, N. Ferrand-Almeida, M. E. Oliveira, J. M. Palmeirim, A. I. Queirós, L. Rogado, \& M. Santos-Reis (eds), Livro Vermelho dos Vertebrados de Portugal. Instituto da Conservação da Natureza, Lisboa. 
Antognazza, C. M., J. R. Britton, C. Potter, E. Franklin, E. A. Hardouin, C. Gutmann Roberts, M. Aprahamian, \& D. Andreou, 2019. Environmental DNA as a non-invasive sampling tool to detect the spawning distribution of European anadromous shads (Alosa spp.). Aquatic Conservation: Marine and Freshwater Ecosystems 29: $148-152$.

Arranz, E., M. Lago, C. Galé, T. Ubide, \& P. Larrea, 2011. Eventos Tectono-Mágmaticos Alpinos en el Registro Geológico de los Pirineos: Inferencias sobre la Evolución del Manto Superior en una Zona Activa . 31-61.

Baddeley, A., \& R. Tuner, 2005. spatstat: an R package for analyzing spatial point patterns. Journal of Statistical Software:1-42, http://www.jstatsoft.org/v12/i06/.

Beng, K. C., \& R. T. Corlett, 2020. Applications of environmental DNA (eDNA) in ecology and conservation: opportunities, challenges and prospects. Biodiversity and Conservation 29: 2089-2121.

Brito, D., R. G. Ambal, T. Brooks, N. De Silva, M. Foster, W. Hao, C. Hilton-Taylor, A. Paglia, J. P. Rodríguez, \& J. V. Rodríguez, 2010. How similar are national red lists and the IUCN Red List?. Biological Conservation 143: 1154-1158.

Casals, F., \& J. R. Sánchez-González (eds), 2020. Guía de las especies Exóticas e Invasoras de los Ríos, Lagos y Estuarios de la Península Ibérica. Proyecto LIFE INVASAQUA. Sociedad Ibérica de Ictiología, Pamplona, Spain

Ceballos, G., P. R. Ehrlich, \& R. Dirzo, 2017. Biological annihilation via the ongoing sixth mass extinction signaled by vertebrate population losses and declines. Proceedings of the National Academy of Sciences 201704949.

Chamberlain, S., V. Barve, D. Mcglinn, D. Oldoni, P. Demest, L. Geffert, \& K. Ram, 2014. rgbif: Interface to the Global Biodiversity Information Facility R Package version 0.7.7. http://cran.r-project.org/package=rgbif.

Clavero, M., \& E. Garcia-Berthou, 2006. Homogenization dynamics and introduction routes of invasive freshwater fish in the Iberian Peninsula. Ecological Applications 16: 2313-2324.

Clavero, M., \& V. Hermoso, 2015. Historical data to plan the recovery of the European eel. Journal of Applied Ecology 52: 960-968.

Clavero, M., F. Blanco-Garrido, \& J. Prenda, 2004. Fish fauna in Iberian Mediterranean river basins: Biodiversity, introduced species and damming impacts. Aquatic Conservation: Marine and Freshwater Ecosystems 14: 575-585.

Collen, B., F. Whitton, E. E. Dyer, J. E. M. Baillie, N. Cumberlidge, W. R. T. Darwall, C. Pollock, N. I. Richman, A. M. Soulsby, \& M. Böhm, 2014. Global patterns of freshwater species diversity, threat and endemism. Global Ecology and Biogeography 23: 40-51.

Collins, R. A., J. Bakker, O. S. Wangensteen, A. Z. Soto, L. Corrigan, D. W. Sims, M. J. Genner, \& S. Mariani, 2019. Non-specific amplification compromises environmental DNA metabarcoding with COI. Methods in Ecology and Evolution 10: 1985-2001.

Contreras-MacBeath, T., D. A. Hendrickson, J. Arroyave, N. Mercado Silva, M. Köck, A. Domínguez Domínguez, O., Valdés González, H. Espinosa Pérez, M. A. Gómez Balandra, W. Matamoros, J. J. Schmitter-Soto, E. SotoGalera, J. M. Rivas González, M. E. Vega-Cendejas, C.
P. Ornelas-García, S. Norris, \& H. . Mejía Guerrero, 2020. The status and distribution of freshwater fishes in Mexico. IUCN and ABQ BioPark, Cambridge, UK and Albuquerque, New Mexico, USA.

Cuttelod, A., N. García, D. A. Malak, H. Temple, \& V. Katariya, 2008. The Mediterranean: a biodiversity hotspot under threat In Vie, J.-C., C. Hilton-taylor, \& S. N. Stuart (eds), The 2008 Review of The IUCN Red List of Threatened Species. IUCN, Gland, Switzerland.

Darwall, W., \& K. Smith, 2006. The Status and Distribution of the Freshwater Fish Endemic to the Mediterranean Basin. IUCN, Gland, Switzerland and Cambridge, UK.

De Vos, J. M., L. N. Joppa, J. L. Gittleman, P. R. Stephens, \& S. L. Pimm, 2015. Estimating the normal background rate of species extinction. Conservation Biology 29: 452-462.

Dirzo, R., H. S. Young, M. Galetti, G. Ceballos, N. J. B. Isaac, \& B. Collen, 2014. Defaunation in the Anthropocene. Science 345: 401-406.

Doadrio, I., S. Perea, P. Garzón-Heydt, \& J. L. González, 2011. Ictiofauna continental española. Bases para su seguimiento. DG Medio Natural y Política Forestal. MARM, Madrid.

Dudgeon, D., A. H. Arthington, M. O. Gessner, Z.-I. Kawabata, D. J. Knowler, C. Lévêque, R. J. Naiman, A.-H. PrieurRichard, D. Soto, M. L. J. Stiassny, \& C. A. Sullivan, 2006. Freshwater biodiversity: importance, threats, status and conservation challenges. Biological Reviews of the Cambridge Philosophical Society 81: 163-182.

Elvira, B., 1995. Conservation status of endemic freshwater fish in Spain. Biological Conservation 72: 129-136.

Filipe, A. F., T. A. Marques, S. Seabra, P. Tiago, F. Ribeiro, L. Moreira Da Costa, I. G. Cowx, \& M. J. Collares-Pereira, 2004. Selection of Priority Areas for Fish Conservation in Guadiana River Basin, Iberian Peninsula. Conservation Biology 18: 189-200.

Fricke, R., W. N. Eschmeyer, \& R. Van der Laan, 2020. Eschmeyer's Catalog of Fishes: Genera, Species, References. San Francisco, CA, http://researcharchive. calacademy.org/research/ichthyology/catalog/fishcatmain. asp.

Gante, H. F., I. Doadrio, M. J. Alves, \& T. E. Dowling, 2015. Semi-permeable species boundaries in Iberian barbels (Barbus and Luciobarbus, Cyprinidae). BMC Evolutionary Biology 15: 1-18.

GBIF, 2020. GBIF Home Page. https://www.gbif.org/citationguidelines.

Gessner, J., P. Williot, E. Rochard, J. Freyhof, \& M. Kottelat, 2010. Acipenser sturio. The IUCN Red List of Threatened Species 2010. Gland

Ramsar Convention on Wetlands, 2018. Global Wetland Outlook: State of the World's Wetlands and Their Services to People. Ramsar Convention Secretariat, Gland, Switzerland.

Guisande, C., \& J. M. Lobo, 2019. KnowBR: Discriminating Well Surveyed Spatial Units from Exhaustive Biodiversity Databases. https://cran.r-project.org/package=KnowBR.

Hermoso, V., \& M. Clavero, 2011. Threatening processes and conservation management of endemic freshwater fish in the Mediterranean basin: A review. Marine and Freshwater Research 62: 244-254. 
Hermoso, V., S. R. Januchowski-Hartley, S. Linke, D. Dudgeon, P. Petry, \& P. McIntyre, 2017. Optimal allocation of Red List assessments to guide conservation of biodiversity in a rapidly changing world. Global Change Biology 12: 3218-3221.

Huang, X., B. A. Hawkins, F. Lei, G. L. Miller, C. Favret, R. Zhang, \& G. Qiao, 2012. Willing or unwilling to share primary biodiversity data: Results and implications of an international survey. Conservation Letters 5: 399-406.

Hughes, K., 2021. The World's forgotten fishes. WWF International, Gland, Switzerland

Itakura, H., R. Wakiya, S. Yamamoto, K. Kaifu, T. Sato, \& T. Minamoto, 2019. Environmental DNA analysis reveals the spatial distribution, abundance, and biomass of Japanese eels at the river-basin scale. Aquatic Conservation: Marine and Freshwater Ecosystems 29: 361-373.

Juffe-Bignoli, D., I. Harrison, S. H. M. Butchart, R. Flitcroft, V. Hermoso, H. Jonas, A. Lukasiewicz, M. Thieme, E. Turak, H. Bingham, J. Dalton, W. R. T. Darwall, M. Deguignet, N. Dudley, R. Gardner, J. Higgins, R. Kumar, S. Linke, G. R. Milton, J. Pittock, K. G. Smith, \& A. van Soesbergen, 2016. Achieving Aichi Biodiversity Target 11 to improve the performance of protected areas and conserve freshwater biodiversity. Aquatic Conservation: Marine and Freshwater Ecosystems 26: 133-151.

Kissling, W. D., J. A. Ahumada, A. Bowser, M. Fernandez, N. Fernández, E. A. García, R. P. Guralnick, N. J. B. Isaac, S. Kelling, W. Los, L. McRae, J. B. Mihoub, M. Obst, M. Santamaria, A. K. Skidmore, K. J. Williams, D. Agosti, D. Amariles, C. Arvanitidis, L. Bastin, F. De Leo, W. Egloff, J. Elith, D. Hobern, D. Martin, H. M. Pereira, G. Pesole, J. Peterseil, H. Saarenmaa, D. Schigel, D. S. Schmeller, N. Segata, E. Turak, P. F. Uhlir, B. Wee, \& A. R. Hardisty, 2018. Building essential biodiversity variables (EBVs) of species distribution and abundance at a global scale. Biological Reviews 93: 600-625.

Laini, A., R. Bolpagni, B. Daniel, G. Burgazzi, S. Guaresch, M. Cédric, \& T. Cancellario, 2018. biomonitoR: An R Package for Calculating Biomonitoring Indices of Running Waters. XXVIII Congress of Italian Ecological Society (SItE) Cagliari.

Lehner, B., \& P. Döll, 2004. Development and validation of a global database of lakes, reservoirs and wetlands. Journal of Hydrology 296: 1-22.

Maceda-Veiga, A., 2013. Towards the conservation of freshwater fish: Iberian Rivers as an example of threats and management practices. Reviews in Fish Biology and Fisheries 23: 1-22.

Marcos, C., L. Arenillas, J. C. Velasco, \& I. Cervera, 2018. Actuaciones para mejorar el estado de conservación de los ciprínidos ibéricos en la provincia de Salamanca. Foresta 72: $68-72$

Miqueleiz, I., M. Bohm, A. H. Ariño, \& R. Miranda, 2020. Assessment gaps and biases in knowledge of conservation status of fishes. Aquatic Conservation: Marine and Freshwater Ecosystems John Wiley \& Sons, Ltd 30: 225-236.

Mora, C., D. P. Tittensor, S. Adl, A. G. B. Simpson, \& B. Worm, 2011. How many species are there on earth and in the ocean?. PLoS Biology 9: e1001127.
Muñoz-Mas, R., \& E. García-Berthou, 2020. Alien animal introductions in Iberian inland waters: An update and analysis. Science of the Total Environment 703: 134505.

Múrria, C., L. O. S. Väisänen, S. Somma, O. S. Wangensteen, M. A. Arnedo, \& N. Prat, 2020. Towards an iberian dna barcode reference library of freshwater macroinvertebrates and fishes. Limnetica 39: 73-92.

Myers, N., R. A. Mittermeier, C. G. Mittermeier, G. A. B. da Fonseca, \& J. Kent, 2000. Biodiversity hotspots for conservation priorities. Nature 403: 853-858.

Pelayo-Villamil, P., C. Guisande, R. P. Vari, A. ManjarrésHernández, E. García-Roselló, J. González-Dacosta, J. Heine, L. González Vilas, B. Patti, E. M. Quinci, L. F. Jiménez, C. Granado-Lorencio, P. A. Tedesco, \& J. M. Lobo, 2015. Global diversity patterns of freshwater fishes - Potential victims of their own success. Diversity and Distributions 21: 345-356.

R Development Core Team, 2019. R: A language and environment for statistical computing. R Foundation for Statistical Computing, Vienna, Austria.

Reid, A. J., A. K. Carlson, I. F. Creed, E. J. Eliason, P. A. Gell, P. T. J. Johnson, K. A. Kidd, T. J. MacCormack, J. D. Olden, S. J. Ormerod, J. P. Smol, W. W. Taylor, K. Tockner, J. C. Vermaire, D. Dudgeon, \& S. J. Cooke, 2019. Emerging threats and persistent conservation challenges for freshwater biodiversity. Biological Reviews 94: 849-873.

Rodrigues, A. S. L., J. D. Pilgrim, J. F. Lamoreux, M. Hoffmann, \& T. M. Brooks, 2006. The value of the IUCN Red List for conservation. Trends in Ecology and Evolution 21: 71-76.

Rodríguez, J. P., 2008. National Red Lists: The largest global market for IUCN Red List Categories and Criteria. Endangered Species Research 6: 193-198.

Rondinini, C., M. Di Marco, P. Visconti, S. H. M. Butchart, \& L. Boitani, 2014. Update or outdate: Long-term viability of the IUCN Red List. Conservation Letters 7: 126-130.

Sales, N. G., O. S. Wangensteen, D. C. Carvalho, K. Deiner, K. Præbel, I. Coscia, A. McDevitt, \& S. Mariani, 2021. Spacetime dynamics in monitoring neotropical fish communities using eDNA metabarcoding. Science of The Total Environment 754: 142096.

Sánchez-Hernández, J., F. Cobo, \& P. A. Amundsen, 2015. A simple approach for assigning the conservation status of freshwater fish based on their natural variability - a case study from the Iberian Ecoregion. Fisheries Management and Ecology 22: 125-133.

SIBIC, 2017. Carta Piscícola Española. Publicación electrónica (versión 02/2017). http://www.cartapiscicola.org/.

Stewart, K. A., 2019. Understanding the effects of biotic and abiotic factors on sources of aquatic environmental DNA. Biodiversity and Conservation Springer Netherlands 28: 983-1001.

Strayer, D. L., \& D. Dudgeon, 2010. Freshwater biodiversity conservation: recent progress and future challenges. J. N. Am. Benthol. Soc. 29: 344-358.

Takahara, T., N. Iwai, K. Yasumiba, \& T. Igawa, 2020. Comparison of the detection of 3 endangered frog species by edna and acoustic surveys across 3 seasons. Freshwater Science 30: 18-27.

Tapley, B., C. J. C. J. Michaels, R. Gumbs, M. Bohm, J. Luedtke, P. Pearce-Kelly, J. J. L. and Rowley, M. Böhm, J. Luedtke, P. Pearce-Kelly, \& J. J. L. Rowley, 2018. The 
disparity between species decription and conservation assessment: a case study in taxa with high rates of species Discovery. Biological Conservation 220: 209-214.

Tedesco, P. A., O. Beauchard, R. Bigorne, S. Blanchet, L. Buisson, L. Conti, J.-F. Cornu, M. S. Dias, G. Grenouillet, B. Hugueny, C. Jézéquel, F. Leprieur, S. Brosse, \& T. Oberdorff, 2017. A global database on freshwater fish species occurrence in drainage basins. Scientific Data 4: 170141.

IUCN, 2020. The IUCN Red List of Threatened Species. Version 2020-2. https://www.iucnredlist.org/

Instituto Chico Mendes de Conservação da Biodiversidade, 2018. Livro Vermelho da Fauna Brasileira Ameaçada de Extinção: Volume VI - Peixes Livro Vermelho da Fauna Brasileira Ameaçada de Extinção. ICMBio, Brasília.

Vila-Gispert, A., C. Alcaraz, \& E. García-Berthou, 2005. Lifehistory traits of invasive fish in small Mediterranean streams. Biological Invasions 7: 107-116.

Waldron, A., A. O. Mooers, D. C. Miller, N. Nibbelink, D. Redding, T. S. Kuhn, J. T. Roberts, \& J. L. Gittleman, 2013. Targeting global conservation funding to limit immediate biodiversity declines. Proceedings of the National Academy of Sciences of the United States of America 110: 12144-12148.
Weigand, H., A. J. Beermann, F. Čiampor, F. O. Costa, Z. Csabai, S. Duarte, M. F. Geiger, M. Grabowski, F. Rimet, B. Rulik, M. Strand, N. Szucsich, A. M. Weigand, E. Willassen, S. A. Wyler, A. Bouchez, A. Borja, Z. Čiamporová-Zat'ovičová, S. Ferreira, K. D. B. Dijkstra, U. Eisendle, J. Freyhof, P. Gadawski, W. Graf, A. Haegerbaeumer, B. B. van der Hoorn, B. Japoshvili, L. Keresztes, E. Keskin, F. Leese, J. N. Macher, T. Mamos, G. Paz, V. Pešić, D. M. Pfannkuchen, M. A. Pfannkuchen, B. W. Price, B. Rinkevich, M. A. L. Teixeira, G. Várbíró, \& T. Ekrem, 2019. DNA barcode reference libraries for the monitoring of aquatic biota in Europe: Gap-analysis and recommendations for future work. Science of the Total Environment 678: 499-524.

WWF, 2020. Living Planet Report 2020 - Bending the curve of biodiversity loss. WWF, Gland, Switzerland.

Zamin, T. J., J. E. M. Baillie, R. M. Miller, J. P. Rodríguez, A. Ardid, \& B. Collen, 2010. National red listing beyond the 2010 target. Conservation Biology 24: 1012-1020.

Publisher's Note Springer Nature remains neutral with regard to jurisdictional claims in published maps and institutional affiliations. 